\title{
HUBUNGAN PENGETAHUAN DENGAN SIKAP TENAGA BASIC LIFE SUPPORT DI PUSKESMAS PANCURBATU KABUPATEN DELISERDANG
}

\author{
Lilis Novitarum ${ }^{1}$, Siti Meilan Simbolon ${ }^{2}$ \\ *Staf Pengajar STIKes Santa Elisabeth Medan
}

\begin{abstract}
Background : Knowledge and attitudes are the result of out through a specific sensing of objects and social interaction so that the formation of a person's actions. Basic Life Support was given an early intervention in the treatment of patients in cardiac arrest (cardiac arrest).

Goal : This study aimed to analyze the relationship between knowledge with attitude of health workers on basic life support in Puskemas Pancur Stone Deli Serdang.

Methods: The method used is descriptive analytic research with cross sectional approach. Samples numbered 32 with a sampling technique is total sampling. Measuring instrument used in this study a questionnaire.

Result $:$ The results of statistical tests chi-square test, $p$ value $=0.014$ was obtained. $P$ value $<0.05$, it indicates there is a relationship of knowledge with the attitude of health workers in health centers BLS Pancur Stone.

Conclusion : Expected to health workers in health centers Pancur stone to further improve and understand basic life support and can take action BLS in the treatment of patients who suffered sudden cardiac arrest, so handled quickly and accurately, as well as a training / seminar on basic life support on a regular basis.
\end{abstract}

Keywords: Knowledge, Attitude, Basic Life Support

\section{PENDAHULUAN}

Kegawatdaruratan merupakan salah satu masalah dalam dunia kesehatan. Keadaan ini dapat terjadi pada kecelakaan, konflik, manusia, maupun bencana. Kedaruratan dapat terjadi kapan saja, dapat menimpa siapa saja,dapat muncul dimana saja, tidak mengenal waktu, tempat, atau objek. Kondisi kegawatdaruratan diantaranya adalah serangan jantung. Angka kejadian kasus yang memerlukan resusitasi jantung paru (RJP) sebagian besar adalah akibat henti jantung mendadak (cardiac arrest). Jantung, paru, dan otak merupakan organ-organ vital, gangguan atau hilangnya fungsi dari salah satu organ ini dapat berakibat kematian. Proses kematian pada cardiac arrest berlangsung dengan mulai berhentinya jantung dan diikuti dengan hilangnya fungsi sirkulasi yang berakibat pada kematian jaringan (Panacea, 2013).

Basic Life Support (BLS) adalah intervensi awal yang dapat diberikan dalam penganan pasien henti jantung, dapat dilakukan oleh semua orang dari golongan ataupun tingkat masyarakat yang sudah memiliki kemampuan dasar dalam melakukan pemberian basic life support. Pada dasarnya komponen yang sangat erat kaitannya dengan bantuan hidup dasar adalah tingkat kesadaran dari korban membuka dan mempertahankan jalan nafas, pemeriksaan fungsi pernapasan, dan pemeriksaan sirkulasi (Gloe, 2005).

Dengan demikian, untuk melakukan tindakan pertolongan pertama pada korban 
yang mengalami henti jantung ada baiknya seorang penolong memang harus memiliki pengetahuan tentang basic life support,

Secara garis besar pengetahuan itu ialah merupakan hasil "tahu" seseorang setelah seseorang tersebut mengadakan penginderaan terhadap suatu objek tertentu melalui panca indera manusia yakni penglihatan, pendengaran, penciuman, rasa dan raba. Pengetahuan tersebut sangat erat kaitannya dengan pendidikan, oleh karena itu pengetahuan bisa kita dapat melalui pendidikan yang formal dan non formal. Sebagai tenaga kesehatan memang disarankan untuk mengetahui bagaimana melakukan tindakan basic life support agar korban yang mengalami henti jantung dapat tertangani dengan cepat dan tepat.

Ada hasil penelitian yang menunjukkan bahwa semakin tinggi pengetahuan seseorang semakin baik dalam pelaksanaan keselamatan pasien (Selleya Cintia Bawelle, J.S.V Sinolungan dan Rivelino S.Hamel). Dalam penelitian ini diperoleh bahwa semakin baik pengetahuan maka sikap juga akan semakin baik (positif).

$$
\text { Sejalan dengan memiliki }
$$

pengetahuan tentang basic life support tenaga kesehatan juga harus bersikap baik dalam melakukan pertolongan. Sikap adalah reaksi atau respon seseorang terhadap suatu stimulus untuk bertindak. Oleh sebab itu sikap erat kaitannya dengan bagaimana cara menyikapi serta melakukan tindakan pertolongan pertama pada seseorang yang mengalami henti jantung. Dengan demikian dapat disimpulkan bahwa pengetahuan tentang basic life support merupakan hal yang paling terpenting dalam penanggulangan korban yang mengalami henti jantung mendadak, dan apabila kita menemukan korban/seseorang yang mengalami henti jantung di rumah sakit, puskesmas, terutama di luar rumah sakit kita dapat memberikan pertolongan pertama pada korban tersebut. Sama halnya dengan sikap penolong yang saling berkaitan. Karena sikap penolonglah yang pertama mendorong korban untuk memberikan pertolongan pertama. Melalui sikap, kita memahami proses kesadaran yang menentukan tindakan nyata dan tindakan yang tidak mungkin dilakukan individu dalam kehidupan sosialnya (Wawan, 2011)

Hal ini didukung dari hasil penelitian yang menunjukkan bahwa indikator untuk sikap harus sejalan dengan pengetahuan, dalam penentuan sikap yang utuh, pengetahuan, pikiran, keyakinan, dan emosi memegang peranan penting (Widodo, 2010).

Selama bertahun-tahun gangguan sistem kardiovaskuler menjadi masalah utama dan menjadi pembunuh nomor satu di Amerika. Miocardium infractions penyebab utamanya, yang diperkirakan setiap hari orang meninggal dunia, dengan angka kematian mencapai 200,000 sampai 300,000 setiap tahunnya. Sedangkan penderita jantung di Indonesia pada tahun 2013 yang lalu diperkirakan mencapai 20 juta atau sekitar $10 \%$ dari penduduk di Indonesia (Depkes, 2013).Menurut konsesus yang dibuat America Heart Association (AHA) pada tahun 2010, kebanyakan kasus tidak sadar adalah kasus kardiogenik (misalnya: henti jantung) sehingga jika sudah dapat dipastikan penyebabnya adalah jantung, atau disaksikannya tanda-tanda serangan jantung (witnessed cardiogenic) maka penanganannya diutamakan kompresi (circulation), kemudian jalan napas (airway) dan napas (breathing). Namun, jika tanda serangan jantung tidak disaksikan atau penyebab tidak sadar belum dapat diketahui secara pasti (notwitnessed) atau sudah pasti bukan jantung (non-kardiogenik) pada assessment 
yang dilakukan tetap diutamakan untuk membebaskan jalan nafas.Data World Health Organization (WHO) juga menyebutkan bahwa serangan jantung masih menjadi pembunuh manusia nomor satu di negara maju dan berkembang dengan menyumbang $60 \%$ dari seluruh kematian. WHO juga menyebutkan rasio penderita gagal jantung di dunia satu sampai lima orang setiap 1000 penduduk. Selain diakibatkan oleh penyakit henti jantung, juga dapat terjadi karena beberapa kecelakaan contohnya terkena arus listrik, tenggelam, tercekik, tersambar petir dan lain sebagainya (jurnal keperawatan : 2014). Komunitas Cardiopulmonary resuscitation (CPR), mencoba pengembangan jutaan penduduk dengan pengembangan kemampuan dasar untuk mempertahankan hidup dalam menit pertama dari suatu keadaan kritis sampai petugas professional datang dan menanganinya. Bahkan harus diusahakan dalam pembuatan percobaan kepada semua orang untuk menjadi anggota kesehatan dalam bantuan hidup dasar. Program ini bermaksud menangani pasien henti jantung baik di rumah sakit ataupun di luar rumah sakit (Gloe, 2005).

Oleh sebab itu,pada fase gawat darurat (golden period) untuk korban yang mengalami henti jantung sangatlah penting baik itu pre ataupun post hospital. Sedini mungkin kita memberikan pertolongan pertama semakin tinggi pula angka keselamatan korban tersebut. Untuk memastikan jantung korban tidak berdetak atau tidak,anda dapat meraba pada arteri karotisnya yang letaknya pada leher.

Berdasarkan hasil survei pendahuluan bahwa para tenaga kesehatan di Puskesmas Pancur Batu juga telah mengikuti pelatihan mengenai basic life support yang dilaksanakan oleh STIKes Santa Elisabeth Medan pada tanggal agustus 2015 yang lalu. Dari hasil pelatihan tersebut didapatkan bahwa belum dievaluasi pengetahuan tindakan basic life support sebagai contoh : tenaga kesehatan belum memahami dimana letak titik tumpu untuk melakukan pompa jantung atau yang lebih kita kenal dengan RJP (resusitasi jantung paru).

Dengan demikian sangat penting rasanya untuk mengetahui, serta memahami konsep dasar basic life support itu sendiri, yang dapat kita peroleh dari proses pembelajaran, ataupun melalui pelatihan khusus serta dapat juga melalui seminar agar dapat diaplikasikan serta dilakukan sesuai dengan standar operasional yang baik dan benar dalam hal memberikan pertolongan pertama.berdasarkan data latar belakang tersebut peneliti tertarik untuk melakukan penelitian dengan judul proposal "Hubungan Pengetahuan Dengan Sikap Tenaga Kesehatan Tentang Basic Life Support (BLS) Di Puskesmas Pancur Batu.

\section{METODE PENELITIAN}

Rancangan penelitian merupakan perencanaan penelitian menyeluruh yang menyangkutsemua komponen dan langkah penelitian dengan mempertimbangkan etika penelitian, sumber daya penelitian dan kendala penelitian (Nursalam, 2013). Desain yang digunakan dalam penelitian ini adalah cross sectional yaitu suatu penelitian untuk mempelajari dinamika korelasi antara faktor-faktor resiko dengan efek, dengan cara pendekatan, observasi atau pengumpulan data sekaligus pada suatu saat (point time approach) artinya tiap subjek penelitian hanya diobservasi sekali saja dan pengukuran dilakukan terhadap status karakter atau variabel subjek pada saat pemeriksaan (Notoatmodjo, 2010) Penelitian ini bertujuan untuk mengidentifikasi hubungan antara pengetahuan dengan sikap tenaga kesehatan 
tentang Basic Life Support (BLS) di Puskesmas Pancur Batu tahun 2015.

\section{POPULASI}

Populasi adalah keseluruhan objek penelitian. Apabila seseorang ingin meneliti semua elemen yang ada dalam wilayah penelitian, maka penelitiannya merupakan penelitian populasi (Arikunto, 2010). Populasi pada penelitian ini adalah tenaga kesehatan (perawat/bidan) di Puskesmas Pancur Batu yang mengikuti pelatihan Basic Life Support (BLS) yang diselenggarakan oleh STIKes Santa Elisabeth Medan sejumlah 32 orang yang terdiri dari perawat dengan lulusan SPK sebanyak 8 orang, perawat yang lulusan D3 Keperawatan sebanyak 10 orang, D3 Kebidanan sebanyak 17 orang, D4 Pendidik sebanyak 2 orang, dan lulusan S1 Keperawatan sebanyak 3 orang.

\section{SAMPEL}

Sampel adalah objek yang diteliti dan dianggap mewakili seluruh populasi. Dalam mengambil sampel penelitian ini digunakan cara atau teknik-teknik tertentu, sehingga sampel tersebut sedapat mungkin mewakili populasinya (Arikunto, 2010).

Pada penelitian ini peneliti menggunakan total sampling artinya sampel yang digunakan adalah total populasi, yaitu semua tenaga kesehatan di Puskesmas Pancur Batu yang mengikuti pelatihan BLS yaitu sebanyak 32 orang.

\section{Pengumpulan Data}

\section{Tempat Penelitian}

Penelitian dilaksanakan di Puskesmas Pancur Batu Kabupaten Deli Serdang. Peneliti mengambil lokasi tersebut karena sesuai dengan hasil data awal setelah dilaksanakannya pelatihan

BLS yang diselenggarakan oleh STIKes Santa Elisabeth Medan belum diadakan evaluasi dari hasil pelatihan tersebut sehingga peneliti berminat untuk menelitinya, dan memenuhi kriteria sampel yang diinginkan oleh peneliti.

\section{Waktu Penelitian}

Penelitian ini dilaksanakan pada Agustus 2015 di Puskesmas Pancur Batu

\section{Sumber Data Penelitian}

a. Data primer

Data primer yaitu data yang diperoleh dari responden melalui kuesioner, kelompok fokus, panel, atau juga data hasil wawancara peneliti dengan narasumber (Sujarweni, 2014). Hasil data primer diperoleh secara langsung dari subjek penelitian melalui observasi check list dan kuesioner.

b. Data sekunder

Data sekunder adalah data yang didapat dari catatan, buku, majalah, laporan pemerintahan, artikel, buku-buku sebagai teori dan lain sebagainya (Sujarweni, 2014). Hasil data sekunder diambil dari tata usaha Puskesmas Pancur Batu

\section{Teknik pengumpulan data}

Menurut Burns, pengumpulan data adalah suatu proses pendekatan kepada subjek dan proses pengumpulan karakteristik subjek yang diperlukan dalam suatu penelitian, langkah-langkah dalam pemgumpulan data bergantung pada rancangan penelitian dan teknik instrumen yang digunakan dalam Nursalam, (2013). Teknik pengumpulan data merupakan cara yang dilakukan peneliti untuk mengungkapkan atau menjaring informasi kuantitatif dari responden sesuai lingkup penelitian (Sujarweni, 2014).

Data dikumpulkan menggunakan kuesioner yang dalam penelitian ini merupakan data primer. Sebelum responden mengisi kuesioner, responden diminta kesediannya untuk menyatakan 
persetujuannya menjadi responden dalam penelitian ini, yang dilampirkan bersama dengan kuesioner yang dibagikan. Setelah semua pertanyaan dijawab, peneliti mengumpulkan kembali lembar jawaban responden dan mengucapkan terima kasih atas kesediaannya menjadi responden.

\section{Instrumen Pengumpulan Data}

Penelitian ini menggunakan kuesioner sebagai instrumen untuk mendapatkan informasi dan data dari responden. Kuesioner adalah sejumlah pertanyaan tertulis yang digunakan untuk memperoleh informasi dari responden dalam arti laporan tentang hal-hal yang dia ketahui (Arikunto,2013). Kuesioner yang digunakan dalam penelitian ini yang dibuat oleh peneliti berdasarkan tinjauan kepustakaan. Kuesioner yang diperoleh digunakan untuk memperoleh data tingkat pengetahuan dan sikap tenaga kesehatan tentang basic life support di Pancur Batu. Kuesioner yang digunakan adalah kusioner tertutup dimana sudah disediakan jawabannya sehingga responden tinggal memilih (Arikunto, 2010).

Instrumen yang digunakan untuk mengelompokkan data penelitian ini berupa angket (kuesioner). Kuesioner terdiri dari 3 bagian yaitu : pertama data demografi yang berisi indentitas tenaga kesehatan. Kedua kuesioner pengetahuan tenaga kesehatan tentang BLS, ketiga kuesioner sikap tenaga kesehatan tentang BLS.

a. Kuesioner data demografi

Kuesioner data demografi terdiri dari, usia, jenis kelamin, tingkat pendidikan, agama, suku, pekerjaan.

b. Kuesioner pengetahuan

Kuesioner pengetahuan ada 25 pertanyaan yang terdiri dari 3 indikator yaitu tahu, memahami, dan aplikasi. Indikator untuk pertanyaan tahu terdapat pada item no $1,6,8,12,14,15,18,20$, indikator pertanyaan memahami terdapat pada item no $2,3,4,5,7,, 11,16,21,25$ dan indikator pertanyaan aplikasi terdapat pada item $9,10,11,13,17,19,22,23,24$. Jenis pertanyaan multiple choice dengan pilihan jawaban A,B,C,D,E apabila jawaban benar diberi skor 1 dan jawaban yang salah diberi skor 0 (nol).

Nilai tertinggi yang diperoleh adalah 25 dan nilai terendah adalah 0 . Skala ukur yang digunakan dalam variabel ini adalah skala ordinal, dimana nilainya dengan menggunakan rumus ststistik menurut Sudjana (2002).

Di mana $\mathrm{P}=$ panjang kelas dengan rentang sebesar 25 (selisih nilai tertinggi dan nilai terendah) dan banyak kelas sebanyak 2 kelas (pengetahuan baik, cukup, kurang) didapatkan panjang kelas sebesar 8. Dengan menggunakan $\mathrm{P}=8$ maka didapatkan nilai interval pengetahuan tenaga kesehatan tentang BLS adalah sebagai berikut :

$18-25=$ pengetahuan baik

$0-17=$ pengetahuan cukup

c. Kuesioner sikap

Kuesioner sikap tenaga kesehatan terdiri dari 25 pernyataan dengan pilihan jawaban sangat setuju (SS), setuju (S), ragu-ragu (RR), tidak setuju (TS), sangat tidak setuju (STS).

Kuesioner terdiri dari pernyataan positif dan negatif.Bila pernyataan positif ataupun negatif terdiri dari jawaban sangat setuju diberi nilai 5, setuju diberi nilai 4 , ragu-ragu diberi nilai 3 , tidak setuju diberi nilai 2 , dan sangat tidak setuju diberi nilai 1.Nilai tertinggi yang diperoleh adalah 125 dan terendah sebesar 25 .

Skala ukur yang digunakan dalam variabel ini adalah rumus statistik menurut (Sudjana, 2002).

$\mathrm{P}=\underline{\text { Rentang kelas }}$

$\mathrm{P}=\underline{125-25}$ 


$$
\begin{aligned}
& \mathrm{P}=\frac{100}{2} \\
& \mathrm{P}=50
\end{aligned}
$$

Dimana P merupakan panjang kelas dengan rentang sebesar 75 (selisih nilai tertinggi dan terendah) dan banyak kelas 2 kelas (sikap postif dan sikap negatif), maka didapatkan panjang kelas sebesar 25 . Dengan menggunakan $\mathrm{P}=25$, maka diperoleh interval sikap tenaga kesehatan tentang BLS sebagai berikut :

$$
\begin{aligned}
& \text { 76-125: sikap positif } \\
& 25-75 \text { : sikap negatif }
\end{aligned}
$$

\section{Pengolahan data}

1. Tahap mengumpulkan data, dilakukan melalui instrumen pengumpulan data.

2. Tahap editing, yaitu memeriksa kejelasan dan kelengkapan pengisian instrumen pengumpulan data.

3. Tahap koding, yaitu proses identifikasi dan klasifikasi dari setiap pertanyaan yang terdapat dalam instrumen pengumpulan data menurut variabelvariabel yang diteliti.

4. Tahap tabulasi data, yaitu memasukkan hasil penghitungan ke dalam bentuk tabel untuk melihat persentase dari jawaban pengolahan data.

5. Analisis data dilakukan terhadap kuesioner. Penelitian ini menggunakan beberapa teknis analisis data. Analisis data yang digunakan dalam penelitian ini adalah analisis univariat. Analisis univariat bertujuan untuk mendeskripsikan karakteristik setiap variabel penelitian. Analisis univariat pada penelitian ini adalah distribusi frekuensi responden berdasarkan umur, jenis kelamin dan pendidikan responden. Apabila telah dilakukan analisis univariat tersebut di atas, hasilnya akan diketahui karakteristik atau distribusi setiap variabel dan dapat dilanjutkan analisis bivariat. (Sujarweni, 2014). Untuk melihat hubungan variabel independen terhadap variabel dependen digunakan uji Chi-Square pada tingkat kepercayaan $95 \%$. Jika nilai $p$ Value < 0,05, maka dapat disimpulkan bahwa ada hubungan antara pengetahuan dengan sikap tenaga kesehatan tentang Basic Life Support (BLS) di Puskesmas Pancur Batu.

6. Tahap skoring, dalam langkah ini peneliti menghitung skor yang diperoleh setiap responden berdasarkan jawaban atas pertanyaan yang diajukan peneliti. Tahap tabulasi data, yaitu memasukkan hasil penghitungan ke dalam bentuk tabel untuk melihat persentase dari jawaban pengolahan data.

7. Analisis data dilakukan terhadap kuesioner. Penelitian ini menggunakan beberapa teknis analisis data. Analisis data yang digunakan dalam penelitian ini adalah analisis univariat. Analisis univariat bertujuan untuk mendeskripsikan karakteristik setiap variabel penelitian. Analisis univariat pada penelitian ini adalah distribusi frekuensi responden berdasarkan umur, jenis kelamin dan pendidikan responden. Apabila telah dilakukan analisis univariat tersebut di atas, hasilnya akan diketahui karakteristik atau distribusi setiap variabel dan dapat dilanjutkan analisis bivariat. (Sujarweni, 2014). Untuk melihat hubungan variabel independen terhadap variabel dependen digunakan uji Chi-Square pada tingkat kepercayaan $95 \%$. Jika nilai $p$ Value < 0,05, maka dapat disimpulkan bahwa ada hubungan antara pengetahuan dengan sikap tenaga kesehatan tentang Basic Life Support (BLS) di Puskesmas Pancur Batu.

\section{Hasil Penelitian}

Hasil penelitian dan pembahasan hubungan tingkat pengetahuan dengan 
sikap tenaga kesehatan tentang Basic Life Support di Puskemas Pancur Batu Kabupaten Deli Serdang yang dilakukan melalui pengumpulan data pada bulan Maret tahun 2016 terhadap 32 orang responden. Berikut ini akan diuraikan karakteristik demografi dan hubungan pengetahuan dengan sikap tenaga kesehatan tentang Basic Life Support.

Jumlah tenaga kesehatan di Puskesmas Pancur saat ini berjumlah 114 orang yang terdiri dari : S1 Dokter gigi sebanyak 3 orang, S1 Dokter umum sebanyak 5 orang, S1 Farmasi sebanyak 1 orang, S1 Keperawatan sebanyak 2 orang, S1 Kesehatan Masyarakat sebanyak 2 orang, D4 Kebidanan sebanyak 4 orang, D3 Kebidanan sebanyak 31 orang, D3 Keperawatan sebanyak 8 orang, D3 Gizi sebanyak 1 orang, S1 Keperawatan sebanyak 2 orang, S1 Kesehatan Masyarakat sebanyak 2 orang , D4 Kebidanan sebanyak 4 orang, D3 Kebidanan sebanyak 31 orang, D3 Keperawatan sebanyak 8 orang, D3 Gizi sebanyak 1 orang, D3 Kesehatan gigi 2 orang. Sedangkan berdasarkan jumlah responden yang mengikuti pelatihan tentang Basic Life Support sebanyak 32 orang tenaga kesehatan yang terdiri dari lulusan SPK sebanyak 8 orang, perawat yang lulusan D3 Keperawatan sebanyak 11 orang, D3 Kebidanan sebanyak 9 orang, D4 Pendidik sebanyak 1 orang, dan lulusan S1 Keperawatan sebanyak 3 orang.

\section{a. karakteristik demografi responden berdasarkan demografi di Puskesmas Pancur Batu Kabupaten Deli Serdang tahun 2016}

\section{Tabel 1}

Distribusi frekuensi karateristik responden berdasarkan demografi

\begin{tabular}{lcc}
\hline Karateristik & f & $\%$ \\
\hline Jenis Kelamin & & \\
Laki laki & 2 & 6,2 \\
Perempuan & 30 & 93,8 \\
Suku & & \\
Batak Karo & 22 & 68,8 \\
Batak Toba & 6 & 18,8 \\
Jawa & 2 & 6,2 \\
Minang & 2 & 6,2 \\
Agama & & \\
Islam & 6 & 18,8 \\
Protestan & 25 & 78,1 \\
Katolik & 1 & 3,1 \\
Pendidikan & & \\
D3 Keperawatan & 10 & 31,2 \\
D3 Kebidanan & 17 & 53,1 \\
D4 Kebidanan & 2 & 6,2 \\
S1 Keperawatan & 3 & 9,4 \\
\hline Berdaskan tabel & 1 & \\
\hline
\end{tabular}

Berdasarkan tabel 1 diperoleh bahwa dari 32 responden yang bekerja sebagai tenaga kesehatan di Puskesmas Pancur Batu mayoritas berjenis kelamin perempuan sebanyak 30 orang $(93,8 \%)$ dan jenis kelamin responden laki-laki sebanyak 2 orang (6,2\%). Pada karakteristik suku responden mayoritas suku batak karo sebanyak 22 orang $(68,8 \%)$, batak toba sebanyak 6 orang $(18,8 \%)$ jawa sebanyak 2 orang $(6,2 \%)$ dan minang sebanyak 2 orang $(6,2 \%)$. Sedangkan pada agama responden diperoleh data mayoritas beragama protestan sebanyak 25 orang $(78,1 \%)$ agama islam sebanyak 6 orang $(18,8 \%)$, katolik sebanyak 1 orang $(3,1 \%)$. Pada karakteristik Pendidikan responden diperoleh data bahwa D3 kebidanan sebanyak 17 orang $(53,1 \%)$, D3 perawat sebanyak 10 orang $(31,3)$, D4pendidik sebanyak 2 orang (6,3\%), S1 sebanyak 3 orang $(9,4 \%)$.
b. Karateristik Pengetahuan Tenaga
Kesehatan Tentang Basic Life Support Di Puskesmas Pancur Batu Kabupaten Deli Serdang Tahun 2015. 
Tabel. 2

Distribusi Frekuensi Berdasarkan Tingkat

Pengetahuan Tenaga Kesehatan

Tentang Basic Life Support

\begin{tabular}{lcc}
\hline Pengetahuan & f & \% \\
\hline Baik & 18 & 56,2 \\
Cukup & 14 & 43,8 \\
Total & $\mathbf{3 2}$ & $\mathbf{1 0 0}$ \\
\hline
\end{tabular}

Berdasarkan tabel 2 diperoleh hasil bahwa pengetahuan tenaga kesehatan tentang BLS yang memiliki pengetahuan baik sebanyak 18 orang $(56,2 \%)$ dan pengetahuan yang cukup sebanyak 14 orang $(43,8)$.

\section{Karateristik Hubungan pengetahuan dengan sikap tenaga kesehatan tentang basic life support di Puskesmas Pancur Batu Kabupaten Deli Serdang Tahun 2015.}

Tabel 3 Distribusi Hubungan Pengetahuan Dengan Sikap Tenaga Kesehatan Tentang Basic Life Support (BLS)

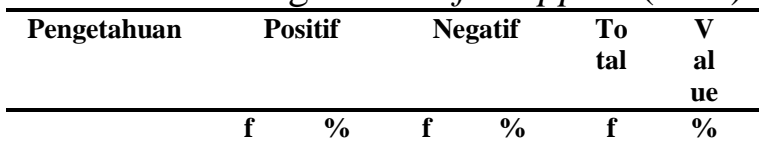

\begin{tabular}{lcccccc} 
Baik & 1 & 72, & 5 & 27, & 18 & 10 \\
& 3 & 2 & & 8 & & 0 \\
cukup & 4 & 28, & 1 & 71, & 14 & 10 \\
& & 6 & 0 & 4 & & 0 \\
\hline
\end{tabular}

Berdasarkan hasil analisis tabel 3 Diperoleh hasil bahwa dari 18 responden dengan pengetahuan yang baik ada 13 orang $(72,2 \%)$ yang memiliki sikap positif dan pengetahuan yang baik dengan sikap yang negatif 5 orang $(27,8 \%)$. Sedangkan pengetahuan yang cukup pada 14 responden yang memiliki sikap negatif sebanyak 10 orang $(71,4 \%)$, dan pengetahuan cukup yang memiliki sikap positif sebanyak 4 orang $(28,6 \%)$.Hasil uji statistik dengan menggunakan uji Chi Square menunjukkan $p=0,014<\alpha 0,05$ ) yang berarti ada hubungan bermakna antara pengetahuan dengan sikap tenaga kesehatan di Puskesmas Pancur Batu Kabupaten Deli Serdang Tahun 2016.

\section{PEMBAHASAN}

\section{A. Tingkat Pengetahuan Tenaga}

Kesehatan di Puskesmas Pancur Batu

Tentang Basic Life Support

Kabupaten Deli serdang Tahun 2015

Berdasarkan hasil penelitian tingkat pengetahuan tenaga kesehatan di Puskesmas Pancur Batu didapatkan bahwa dari 32 orang responden dengan pengetahuan baik sebanyak 18 orang (56,2\%), dan pengetahuan yang cukup sebanyak 14 orang (43,8\%). Peneliti berasumsi tenaga kesehatan di Puskesmas Pancur Batu memiliki pengetahuan yang baik dikarenakan memperoleh pendidikan serta informasi yang cukup baik tentang BLS.

Hasil penelitian ini didukung oleh penelitian yang dilakukan oleh Widodo (2010) di Ruang Intensif RSUD dr Moewardi Surakarta tahun 2010 menunjukkan bahwa pengetahuan perawat (tenaga kesehatan) dikategorikan baik karena memiliki pengetahuan yang tinggi dikarenakan perawat yang bekerja di ruang ICVU RSUD Dr.Moewardi Surakarta telah mendapatkan pendidikan dan pelatihan tentang penanganan pasien dengan gangguan sistem kardiovaskuler khususnya Infark Miokard Akut, diantaranya yaitu pelatihan BCLS dan ACLS.

Pengetahuan adalah merupakan hasil "tahu" dan ini terjadi setelah orang mengadakan penginderaan terhadap suatu objek tertentu. Penginderaan terhadap obyek terjadi melalui panca indra manusia yakni penglihatan, pendengaran, penciuman, rasa dan raba dengan sendiri. Pada waktu pengindraan sampai menghasilkan pengetahuan tersebut sangat dipengaruhi oleh intesitas perhatian 
persepsi terhadap objek. Sebagian besar pengetahuan manusia diperoleh melalui mata dan telinga. (Notoatmodjo, 2003).

Pengetahuan responden tentang BLS juga ditemukan kategori cukup, hal ini disebabkan tenaga kesehatan yang bekerja di Puskesmas Pancur Batu mempunyai latar belakang yang berbedabeda salah satunya pendidikan, dan lama bekerja yang berbeda serta minimnya pengalaman bekerja dan pelatihan tentang basic life support akan mempengaruhi seseorang dalam memperoleh informasi.Pengetahuan sangat erat kaitannya dengan pendidikan, pendidikan didapatkan secara formal dan non formal. Pengetahuan responden tentang BLS termasuk kategori baik, hal ini karena tenaga kesehatan cukup dalam mendapat pendidikan dan informasi tentang BLS. Pengetahuan cukup dikarenakan, sebagian besar responden yang mengikuti pelatihan yang diselenggarakan oleh STIKes Santa Elisabeth Medan ialah lulusan D3 kebidanan yang kemungkinan besar kurang mendapatkan pendidikan serta informasi tentang basic life support. Sebagaimana disampaikan Notoatmodjo (2010) yang menjelaskan bahwa pengetahuan berhubungan dengan berbagai faktor meliputi tingkat pendidikan,informasi, sosial budaya, pengalaman serta umur. Sehingga belum berarti seseorang yang berpengetahuan tinggi mutlak berpendidikan tinggi pula, karena banyak faktor yang berhubungan dengan pengetahuan seseorang tersebut. Faktor umur juga mempengaruhi tingkat pengetahuan tenaga kesehatan itu baik yakni mayoritas responden termasuk pada usia dewasa awal antara (20-40 tahun) dalam artian mampu menyelesaikan masalah melalui cara yang logis dengan memanfaatkan kemampuan belajar dan pengalaman hidup.

\section{B. Sikap Responden Pada Tenaga Kesehatan Di Puskesmas Pancur Batu}

Hasil yang diperoleh dari 32 responden di Puskesmas Pancur Batu ditemukan bahwa responden yang memiliki sikap positif sebanyak 17 orang $(53,1 \%)$ dan responden yang memiliki sikap negatif sebanyak 15 orang (46,9\%). Jadi, dari hasil penelitian diperoleh hasil bahwa sikap responden dalam melakukan tindakan BLS dikategorikan memiliki sikap yang positif. Hasil penelitian ini didukung oleh penelitian yang dilakukan Ghofar (2015) Hubungan Antara Pengetahuan Dan Sikap Perawat Dengan Kemampuan Teknikal Perawat Dalam Pelaksanaan Oral Hygiene Pada Penderita Stroke menunjukkan bahwa sebagian besar sikap perawat cukup baik (positif) dalam merespon tindakan oral hygiene pada pasien stroke hal ini dikarenakan kesiapan peraway untuk bereaksi terhadap pelaksanaan oral hygiene.

Menurut Notoadmodjo (2010) sikap merupakan reaksi atau respon yang masih tertutup terhadap suatu stimulus atau objek. Sikap (attitude) merupakan konsep paling penting dalam psikologi sosial yang membahas unsur sikap baik sebagai individu maupun kelompok. Banyak kajian dilakukan untuk merumuskan pengertian sikap, proses terbentuknya sikap, maupun perubahan Wawan (2011).

Ada beberapa faktor yang mempengaruhi sikap responden positif di antaranya memiliki cara pandang yang baik dalam merespon sesuatu termasuk tindakan BLS, juga dipengaruhi oleh pengalaman bekerja. Tenaga kesehatan di Puskesmas Pancur Batu sebagian besar memiliki pengalaman bekerja di atas 5 tahun, sehingga memiliki sikap yang positif. Sikap yang baik juga terbentuk karena adanya proses pertimbangan terhadap 
stimulus dari sikap tenaga kesehatan dalam memberikan penanganan kegawatdaruratan secara cepat dan tepat serta dalam penentuan sikap seseorang, pengetahuan, pikiran, keyakinan, dan emosi memegang peranan penting, oleh karena itu indikator untuk sikap harus sejalan dengan pengetahuan sehingga meningkatkan sikap yang positif.

\section{Hubungan Pengetahuan Dengan Sikap Tenaga Kesehatan Tentang BasicLife Support (BLS) di Puskesmas Pancur Batu Kabupaten Deli Serdang Tahun 2015}

Hasil penelitian ada hubungan pengetahuan dengan sikap pada tenaga kesehatan di Puskesmas Pancur Batu Kabupaten Deli Serdang dengan hasil penelitian menunjukkan nilai $p=0,014$ dengan hasil nilai $p<0,05$ yang memiliki makna adanya hubungan antara pengetahuan dengan sikap tenaga kesehatan di Puskesmas Pancur Batu Kabupaten Deli Serdang.

Hasil penelitian yang dilakukan didapatkan hasil sebagai berikut, bahwa pengetahuan tenaga kesehatan tentang basic life support memiliki sikap yang positif. Hal ini dapat terjadi karena tenaga kesehatan di Puskesmas Pancur Batu memperoleh pengetahuan tentang basic life support cukup serta dipengaruhi juga oleh pengalaman bekerja tenaga kesehatan di Puskesmas Pancur Batu minimal 5 tahun pengalaman kerja, dan juga tingkat pendidikan tenaga kesehatan disana mayoritas D3 kebidanan dan D3 keperawatan.

Hasil penelitian tersebut sesuai dengan pendapat yang disampaikan Selleya, dkk (2013) bahwa pengetahuan merupakan hal yang domain yang sangat penting untuk terbetuknya suatu tindakan seseorang. Tingkat pengetahuan akan mempengaruhi sikap seseorang dalam melakukan tindakan BLS. Dengan pengetahuan tersebut seseorang akan lebih mudah dalam memberikan tindakan BLS.

Notoadmodjo (2010) pengetahuan (knowledge) adalah hasil tahu dari manusia dan ini terjadi setelah orang mengadakan penginderaan terhadap suatu objek tertentu. Dan beliau juga menjelaskan bahwa semakin tinggi tingkat pengetahuan seseorang, maka semakin tinggi pula seseorang memahami pentingnya melakukan kegiatan untuk mencapai tujuan.

Pada penelitian Widodo (2010) menunjukkan bahwa sikap perawat dalam penanganan pasien yang Infark Miokard Akut baik dikarenakan pengetahuan sejalan dengan sikap yang berarti jika seseorang yang memilki pengetahuan yang baik maka akan bersikap baik pula.

Pada penelitian ini dapat juga dilihat bahwa tenaga kesehatan yang memiliki pengetahuan yang cukup dengan sikap yang negatif dikarenakan minim dalam memperoleh informasi tentang BLS dan tenaga kesehatan yang mengikuti pelatihan tersebut sebagian besar lulusan D3 kebidanan yang dalam menempuh pendidikannya tidak mendapat pelajaran tentang BLS disertai juga pengalaman bekerja yang masih terbilang baru. Untuk dapat lebih memperbaiki dan meningkatkan tingkat pengetahuan cukup dengan sikap yang negatif dengan cara cepat tanggap dalam memperoleh informasi tentang Basic Life Support dan tidak menutup kemungkinan untuk mengikuti seminar ataupun pelatihan tentang BLS yang diselenggarakan oleh rumah sakit ataupun institusi lain yang bekerjasama dengan Puskesmas Pancur Batu agar nantinya dapat serta mengaplikasikan ilmu tentang BLS yang telah dimilikinya dan cepat tepat dalam melakukan tindakan BLS terhadap pasien yang mengalami kondisi 
kegawatdaruratan terlebih pada pasien yang henti jantung mendadak, (cardiac arrest). Pengetahuan berkaitan dengan sikap supaya meningkatkan pengetahuan tenaga kesehatan secara bertahap atau berjenjang dengan mengikuti seminar dan pelatihan, sehingga meningkatkan sikap yang positif.

Menurut Notoadmodjo 2004 sikap hadir didasari dari pengetahuan dan pemahaman seseorang tentang sesuatu objek atau masalah. Sikap yang dimaksud dalam penelitian ini adalah keseluruhan sikap tenaga kesehatan tentang Basic Life Support.

\section{Kesimpulan}

Berdasarkan hasil penelitian dengan jumlah sampel 32 responden mengenai Hubungan Pengetahuan Dengan Sikap Tenaga Kesehatan Di Puskesmas Pancur Batu Kabupaten Deli Serdang Tahun 2015 maka dapat disimpulkan:

1. Pengetahuan Tenaga Kesehatan Di Puskesmas Pancur Batu Kabupaten Deli Serdang menunjukkan bahwa responden yang memiliki tingkat pengetahuan (tahu, memahami, dan aplikasi) yang baik dengan hasil 56,2\% .

2. Sikap Tenaga Kesehatan Di Puskesmas Pancur Batu Kabupaten Deli Serdang menunjukkan bahwa responden memiliki sikap yang positif dengan hasil 53,1\%.

3. Berdasarkan uji chi square, didapatkan nilai $p=0,014$, hal ini menunjukkan bahwa ada hubungan pengetahuan dengan sikap tenaga kesehatan tentang Basic Life Support di Puskesmas Pancur Batu.

\section{Saran}

Berdasarkan hasil penelitian dengan jumlah sampel 32 responden dengan judul hubungan pengetahuan dengan sikap tenaga kesehatan tentang Basic Life
Support di Puskesmas Pancur Batu Kabupaten Deli Serdang Tahun 2015, sebagai berikut:

1. Teoritis

Diharapkan penelitian ini dapat menjadi sumber informasi untuk meningkatkan pengetahuan dan sikap tenaga kesehatan serta lebih memahami pelaksanana dalam melakukan tindakan Basic Life Support (BLS) Di Puskesmas Pancur Batu, pelaksanana dalam melakukan tindakan Basic Life Support (BLS) Di Puskesmas Pancur Batu.

2. Praktis

2.1 Bagi Institusi pendidikan STIKes Santa Elisabeth Medan

Diharapkan penelitian ini dapat menjadi literature dan menjadi bahan ajar bagi mahasiswa/i dibidang kegawatdaruratan terkhusus dalam memberikan tindakan Basic Life Support (BLS) harus paham dalam pelaksanaan secara teori maupun praktek.

2.2 Bagi Tenaga Kesehatan

Hasil penelitian ini diharapkan bagi tenaga kesehatan harus mengetahui, memahami, tentang BLS dan mampu mengaplikasikan hasil pengetahuannya tentang Basic Life Support (BLS) sehingga bila mendapat korban / pasien dengan henti jantung mendadak dapat segera tertangani.

\section{DAFTAR PUSTAKA}

American Heart Asosication, (2011). Adult Basic Life Support. 2010 American Hearth Assiciation Guidelines For Cardiopulmonary Resuscition And Emergency Cardiovaskular Care. Greenvile Avenue : American Hearth Association.

Arikunto, S. (2006). Prosedur Penelitian: Suatu Pendekatan Praktik. Edisi Revisi VI. Jakarta : Asdi Mahasatya 
Arikunto. (2013). Manajemen Penelitian. Jakarta : Rineka Cipta

Arikunto (2010). Metodologi Penelitian Kesehatan. Jakarta: PT Rineka Cipta

Dahlan, Sopiyudin. (2012). Statistik Untuk Kedokteran Dan Kesehatan. Jakarta: Salemba Medika

Dahlan, dkk (2014). Pengaruh Pendidikan Pendidikan Kesehatan Tentang Bantuan Hidup Dasar Terhadap Tingkat Pengetahuan Tenaga Kesehatan Puskesmas Wori Kecamatan Wori Kabupaten Minahasa Utara (online) http://ejournal.unsrat.ac.id/index.php/ $\mathrm{jkp} /$ article/view/4058_diakses 11Desember 2014

Gloe, Donna S (2005). Sheeny's Manual Of Emergency Care. United State Of America: Elseiver Mosby

Gofar, Abdul (2014) Hubungan Antara Pengetahuan Dan Sikap Perawat Dengan Kemampuan Teknikal Perawat Dalam Pelaksanaan Oral Hygiene Pada Penderita Stroke (online)

https://scholar.google.co.id/scholar?q =Hubungan+Antara + Pengetahuan $+\mathrm{D}$ $\underline{\text { ant }}$

$\underline{\text { Sikap+Perawat+Dengan+Kemampua }}$ $\underline{\text { n+Teknikal+Perawat+Dalam+Pelaks }}$ $\underline{\text { ana }}$

an+Oral+Hygiene+Pada+Penderita+ Stroke.\&btnG $=\& h \mathrm{l}=\mathrm{id} \&$ as $\_s d t=0 \% 2$ C5 diakses 23 Januari 2014

Jacob,dkk. (2014). Buku ajar Clinical Nursing Procedures. Jilid Dua. Tangerang Selatan : Binapura Aksara.
Notoatmodjo. (2010). Metode Penelitian Kesehatan. Jakarta : Rineka Cipta.. Nursalam. (2011). Konsep dan Penerapan Metodologi Penelitian Ilmu Keperawatan .Jakarta : Salemba Medika.

Pakpahan.(2014). Hubungan Pengetahuan Bantuan Hidup Dasar Dengan Sikap Mahasiswa Semester VIII Tentang Penanganan Pasien Henti Jantung Di STIKes Santa Elisabeth Medan 2015. Medan.

Sujarweni. (2014). Metodologi Penelitian Keperawatan. Yogyakarta : Gava Media Sudjana. (2002). Metode Statistika. Bandung : Tarsito Swasanti,Winkanda Sastria. (2014). Panduan Praktis Pertolongan Pertama Pada Kedaruratan. Yogyakarta :

Katahati.

Bawelle, dkk (2013) Hubungan Pengetahuan Dengan Sikap Perawat Dengan Pelaksanaan Keselamatan Pasien (Patient Safety) Di Rangan Rawat Inap RSUD Liun Kendage Tahuna (online) http://ejournal.unsrat.ac.id/index.php/jk p/article/view/2237 diakses 12 Febuari 2014

Tim Bantuan Medis Panacea. (2014) Basic Life Support Buku Panduan. Edisi13.Jakarta : EGC

Wawan \& Dewi. (2011). Teori \& Pengukuran Pengetahuan, Sikap dan Perilaku Manusia. Yogyakarta : Nuha Medika

Widodo. (2010) Hubungan Pengetahuan Perawat Tentang Kegawatdaruratan Infark Miokard Akut Dengan Sikap Perawat Dalam Penanganan Pasien 
Hubungan Pengetahuan dengan Sikap Tenaga Basic Life Support di Puskesmas Pancurbatu Deliserdang

Infark Miokard Akut Di Ruangan

Intensif RSUD Moewardi Surakarta

Tahun $\quad 2010 \quad$ (online)

http://jurnal.poltekkes-

solo.ac.id/index.php/Int/article/view/

$\underline{36}$ diakses 10 januari 2014 
Hubungan Pengetahuan dengan Sikap Tenaga Basic Life Support di Puskesmas Pancurbatu Deliserdang 